\title{
Alteration of Ecdysteroid Titre by Thyroxine and Juvenile Hormone Analogue (Methoprene) in Bombyx mori (Lepidoptera: Bombycidae)
}

Pengaruh Tiroksin dan Analog Hormon Juvenil (Metopren) terhadap Pola Titer Ekdisteroid Bombyx mori (Lepidoptera: Bombycidae)

\author{
Intan Ahmad ${ }^{1 *}$, Resti Rahayu ${ }^{2}$, Agus D. Permana ${ }^{1}$, Sita Astari ${ }^{1}$ \\ ${ }^{1}$ School of Life Sciences and Technology Bandung Institute of Technology, Jl. Ganesha 10 Bandung 40132 \\ Indonesia Phone/Fax: +62-22-251-5033 E-mail: intan@itb.ac.id *Penulis untuk korespondensi \\ ${ }^{2}$ Department of Biology, Andalas University, Padang, Indonesia
}

\begin{abstract}
Abstrak
Penelitian ini dilakukan untuk mengetahui pengaruh hormon tiroksin dan analog hormon juvenil (metopren) terhadap pola titer hormon ekdisteroid hemolimf selama instar lima Bombyx mori. Instar dua B. mori diberi pakan daun murbei yang telah diberi tiroksin dengan konsentrasi 1500 ppm. Larva kemudian dibiarkan ganti kulit sampai instar tiga dan empat tanpa perlakuan. Tujuh puluh dua jam setelah ganti kulit pada instar lima, larva disuntik sebanyak $10 \mu \mathrm{l}$ metopren dengan konsentrasi 15 atau 25 ppm. Titer ekdisteroid hemolimf dideteksi dengan Kromatografi Cair Kinerja Tinggi. Hasil yang diperoleh menunjukkan bahwa perlakuan dengan tiroksin ataupun kombinasi tiroksin-metopren menyebabkan terjadinya perubahan pola titer ekdisteroid dibandingkan dengan kontrol. Ekdisteroid terdeteksi dua hari lebih awal pada perlakuan tiroksin dan titer ekdisteroid pada puncak tertinggi lebih tinggi jika dibandingkan dengan kontrol. Kombinasi tiroksin-metopren tampaknya menyebabkan penekanan terhadap titer ekdisteroid. Hal ini terlihat dengan terjadinya penurunan titer ekdisteroid segera setelah penyuntikan dengan metopren sebelum mencapai titer puncak tertinggi.
\end{abstract}

Kata kunci: Bombyx mori, tiroksin, metopren, ekdisteroid, titer

Diterima: 30 Desember 2006, disetujui: 02 Maret 2007

\section{Introduction}

Application of hormones to Bombyx mori to improve the quality of silk has been suggested by many reports. For example, Thyagaraja et al., (1991) reported that thyroxine could be used to shorten larval period and at the same time increased cocoon and silk weight up to $150 \%$ as compared to controls, while Akai et al., (1985) reported that juvenile hormone analogue (methoprene) could be used to increase silk ratio up to $30 \%$ over control. The similar result was also reported by Miranda et al., (2002) topical application of methoprene caused an increase in the weight of B. mori silkgland and cocoon.
Despite the fact that application of either thyroxine or juvenile hormone analogue can affect the cocoon and silk weight; we have decided to study the effects of the combination of the two substances, thyroxine and methoprene, to the larval period and silk gland and cocoon quality of $B$. mori.

Application of thyroxine would affect the insect's physiological processes. For example, treatment with thyroxine to $B$. mori larvae increased the ecdysteroid titre almost two-fold on larvae treated during first instar to fifth instar and 3.5-fold for larvae treated during second instar only as compared to untreated larvae. Treatment with thyroxine also increased the production of larvae haemolymph protein 
(Thyagaraja et al., 1991). Meanwhile, treatment with juvenile hormone analogue (Methoprene) would inhibit secretion of prothoracicotropic hormone and synthesis of ecdysteroid (Sakurai et al., 1998).

During fifth instar of $B$. mori under normal conditions, ecdysteroid titre in haemolymph increased significantly on the fourth day and after that, it increased gradually and fluctuated each day (Sakurai et al., 1998). The fluctuation was due to the existence of juvenile hormone.

Considering those facts, we thought it was necessary to study the effects of the applications of combination of thyroxine and methoprene on haemolymph ecdysteroid titre pattern during fifth instar of $B$. mori, in order to see if the combination of both hormones would cause an alteration in haemolymph ecdysteroid titre pattern during fifth instar of $B$. mori compared to that under the normal conditions.

\section{Materials and Method}

\section{Experimental insects}

B. mori type Polyhibrid bivoltine C.301 were reared under laboratory conditions in the School of Life Sciences and Technology, Bandung Institute of Technology, Indonesia. The animals were reared on mulberry leaves at $25-27^{\circ} \mathrm{C}, 85 \% \mathrm{RH}$ and $12 \mathrm{~h}$ light: $12 \mathrm{~h}$ dark cycle.

\section{Preparation of thyroxine solution}

Thyroxine was obtained from thyroid powder Grade II (Sigma Ltd. USA). $150 \mathrm{mg}$ thyroxine was diluted in $5 \mathrm{ml}$ sodium hydroxide $0.1 \mathrm{~N}(4 \mathrm{~g} \mathrm{NaOH}+1000 \mathrm{ml}$ aquadest). The solution then was added by 95 $\mathrm{ml}$ aquadest to obtain a thyroxin solution with concentration of $1.5 \mathrm{mg} / \mathrm{ml}(1500 \mathrm{ppm})$ (Thyagaraja et al., 1991).

\section{Preparation of methoprene solution}

Methoprene was obtained from Altosid $1.3 \mathrm{G}$ (Sandoz Crop). Altosid contained 1.3\% methoprene as an active ingredient. In this experiment, the concentrations of methoprene used were 15 and $25 \mathrm{ppm}$. To obtain a $15 \mathrm{ppm}$ methoprene solution, an amount of 1.15 gram of Altosid was diluted in 1 liter of aquadest, while 1.92 gram of Altosid was needed to make a 25 ppm methoprene solution.

\section{Treatment of Bombyx mori}

Thyroxine was given ad libitum during the second instar. The minced leaves were dipped in thyroxine solution for 3 minutes, then left to dry. Third and fourth instars were not treated with thyroxine. Then, 72 hours after molting to fifth instar, treatment using methoprene was applied. Each individual was injected with $10 \mu \mathrm{l}$ of 15 or $25 \mathrm{ppm}$ methoprene solutions on the segmental junction at the lateral part of the larva.

\section{Removal of haemolymph and isolation of ecdysteroid}

Fifty $\mu \mathrm{l}$ of haemolymph was drained every day from each fifth instar larva that has been anesthetized using ether, through a cut on its proleg. The haemolymph sample was put into a $1.5 \mathrm{ml}$ microtube and was added with $500 \mu \mathrm{l} \mathrm{mix}$ of acetone-ethanol (1:1). The mixture then was stirred and kept in a temperature of $-20^{\circ} \mathrm{C}$ until further processing.

Ecdysteroid isolation was conducted using method from Beydon (1985). Haemolymph was extracted using acetoneethanol $(1: 1)$ with ratio of $1: 10$, and then the mixture was centrifuged at $10,000 \mathrm{~g}$ for 10 minutes. The supernatant was removed and the remaining solution was re-extracted. Supernatants from the first and second centrifugation were mixed and evaporated, then $500 \mu \mathrm{l}$ hexane-methanol $80 \%$ (1:1) was added. When hexane-methanol phase (marked with the formation of a borderline between hexane and methanol) has occurred, the methanol phase (lower part) that contained ecdysteroid was removed and evaporated. The product was diluted in methanol and filtered using "Sep-Pak ${ }^{\circledR}$ Cartridges" and analyzed by HPLC.

Quantitative and qualitative analysis of ecdysteroid by HPLC

Ecdysteroid diluted in methanol was analyzed by HPLC type Kromatopak Shimadzu CR-7A plus. The type of column used was 
Shim-pack CLC-ODS C18 $0.6 \mathrm{~mm}$ in diameter and $15 \mathrm{~cm}$ in length. The mobile phase used was a mixture of methanol-water (9:1) mixed isocratically. The flow rate was $1 \mathrm{ml} /$ minute and the wavelength used to detect ecdysteroid was $254 \mathrm{~nm}$ (Beydon, 1985).

Before conducting the analysis, first the mobile phase was filtrated using cellulose acetate membrane filter (PTFE) $0.45 \mu \mathrm{m}$. Ecdysteroid standard used as a comparison was ecdyson (obtained from Sigma Ltd. USA). Ecdyson standard was diluted with methanol pro analysis. To obtain the required concentration, further dilution was needed.

Qualitative analysis was conducted by comparing retention time between standard ecdysteroid and the sample. If the sample contained compounds that had the same retention time with the standard ecdysteroid, then the compound was assumed to be ecdysteroid. Co injection of standard and sample were conducted to confirm the existence of ecdysteroid in the sample.

Quantitative analysis to determine ecdysteroid concentration was conducted by comparing area width of the sample to that of the standard on a standard calibration curve. The curve was made by plotting the area width of the ecdysteroid standard to its concentration.

\section{Results and Discussion}

\section{Ecdysteroid titre in haemolymph of fifth instar of Bombyx mori}

As can be seen in Figure 1, ecdysteroid was detected two days earlier in larvae which had been treated with thyroxine during the second instar, as compared to the control (untreated) larvae.

Ecdysteroid in control larvae was first detected on the sixth day with the concentration of $99.83 \mu \mathrm{g} / \mathrm{ml}$ and increased until the seventh day $(115.45 \mu \mathrm{g} / \mathrm{ml})$. Ecdysteroid titre on the seventh day was the highest during the fifth instar and would decrease until larvae stopped eating and started making cocoon. The lowest titre was achieved on the eight day $(58.45 \mu \mathrm{g} / \mathrm{ml})$, two days before larvae started making cocoon.
In the larvae treated with thyroxine during the second instar, ecdysteroid first detected on the fourth day. After the fourth day, ecdysteroid titre in B. mori haemolymph would increase gradually until reaching the maximum titre on the sixth day. The maximum peak of the titre was $33.34 \%$ higher than that of the control. This peak was detected one day earlier in treated larvae compared to the control.

In B. mori larvae treated with thyroxine and methoprene, there was a suppressing pattern in the haemolymph ecdysteroid titre. Ecdysteroid titre drastically decreased shortly after application of $15 \mathrm{ppm}$ methoprene, from 82.71 to $64.71 \mu \mathrm{g} / \mathrm{ml}$. Two days after the application, ecdysteroid titre had suffered a decrease then increased drastically and reached the maximum titre peak on the seventh day (three days after treatment). Meanwhile, in the combination of thyroxine and methoprene of higher concentration (1500/25 ppm), one day after the application the ecdysteroid titre was $81.72 \mu \mathrm{g} / \mathrm{ml}$ and did not differ significantly to the ecdysteroid titre one day earlier. Two days after treatment, the ecdysteroid titre increased again, but much lower compared to that in larvae treated using methoprene $15 \mathrm{ppm}$. In comparison, in larvae without methoprene treatment (control and larvae treated with thyroxine only), the ecdysteroid titre kept increasing and did not show any decrease before reaching the maximum ecdysteroid titre.

The maximum peak of ecdysteroid titre in larvae treated using combination of thyroxine-methoprene 1500/15 ppm was about $32.14 \%$ or 1.32 times higher than that of the untreated larvae. In larvae treated using combination of thyroxine and higher concentration of methoprene (1500/25 ppm), the maximum titre peak did not differ much from that of the control. Generally, application of a higher concentration of methoprene (25 ppm) caused a lower and relatively more stable ecdysteroid titre during fifth instar than that of other treatments.

\section{Ecdysteroid titre in haemolymph of fifth instar of Bombyx mori}

Thyagaraja et al., (1991) suggested that $B$. mori feeding on thyroxine at earlier instar 
would eventually stimulate the brain to release prothoracicotropin and regulate the prothoracic gland to release a precocious amount of ecdyson at the later instar. The present experiments seemed to substantiate their view as shown by comparison to the controls, in larvae treated with thyroxine during their second instars, ecdysteroid was detected two days earlier with titre of $82.71 \%$, and had a maximum titre peak of $33.34 \%$ or 1.33 times higher.

Interestingly, applications of methoprene to fifth instar of $B$. mori seemed to cause a change in ecdysteroid biosynthesis. This hypothesis is supported by $\mathrm{Mu}$ and Leblanc (2004 in Tuberty \& McKenney, 2005) who reported that exposure of JHAs caused a reduction in ecdysteroid gene expression, and it was possibly caused by competitive binding of the JHAs to the receptors required for regulating ecdysteroid production. In this research, it could be seen, for example, by a drastic decrease in ecdysteroid titre shortly after methoprene applications, from 82.71 to $64.71 \mu \mathrm{g} / \mathrm{ml}$, during treatment with combination of thyroxine and methoprene 15 ppm. In B. mori larvae treated with a higher concentration of methoprene (25 ppm), the average of ecdysteroid titre was lower and relatively more stable than that of other treatments. The results of this study were generally almost identical to the results reported by Watson et al., (1987) that the application of (7S)-hydroprene, an analogue to juvenile hormone, to Manduca sexta larvae would stimulate the prothoracic gland to produce ecdyson. This result also supported by Tuberty \& McKenney (2005) who reported that exposure to juvenile hormone analogues affect ecdysteroid concentrations in vivo in crabs and shrimps larvae. The exposure of JHAs caused fluctuations in ecdysteroid concentrations throughout their larval stages.

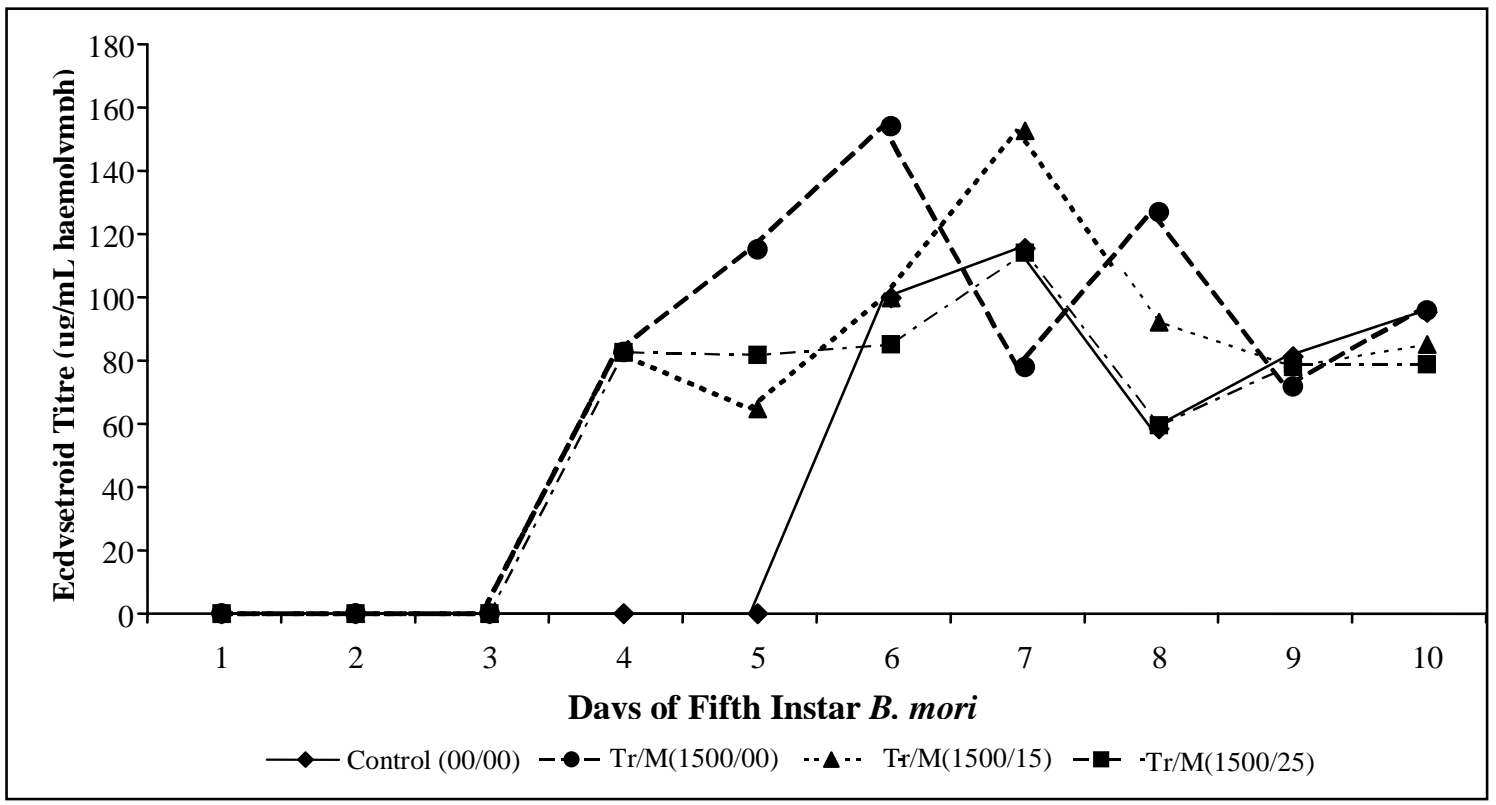

Figure 1. Effect of thyroxine feeding and methoprene injection on ecdysteroid titre during the last larval instars. Control without hormone treatment (00/00); treatment with thyroxine (Tr) 1500 ppm given during second instar (1500/00); combination of thyroxine $1500 \mathrm{ppm}$ with methoprene (M) $15 \mathrm{ppm}(1500 / 15)$; combination of thyroxine $1500 \mathrm{ppm}$ with methoprene $25 \mathrm{ppm}$ (1500/25). Quantity of ecdysteroid was determined using HPLC and was calibrated using ecdyson as a standard of comparison. Day one (0 hours) was the first day after molting to fifth instar. 
In the present experiment, at first, it seemed that the drastic decrease in ecdysteroid titre occurred after applications of a lower concentration of methoprene (15 ppm), even though the titre would rapidly increase again in a large amount. The stronger effect of thyroxine-methoprene combination with lower concentration than that of the higher concentration shortly after applications of methoprene (one day after application) was probably due to the characteristics of most hormones. Hormones have optimum dose/concentration; therefore, increasing the amount of hormones will not necessarily increase the performance.

Under normal conditions, the production of juvenile hormone titre by the corpora allata in the middle of the fifth instar of $B$. mori is supposed to decrease or stop. But, because of the application of methoprene during stadium of 72 hours, the titre of juvenile hormone inside the blood remained high. It led to a change on the normal condition of ecdysteroid hormone inside the insect's body.

Ecdysteroid titre that decreased shortly after an application of methoprene would bounce back and reach the maximum titre peak on the seventh day (three days after the treatment). It was probably because methoprene in haemolymph had been decreased or totally vanished. The same phenomenon was reported by Trivedy et al., (1995) in which fifth instar of B. mori treated with a low dose of juvenile hormone R394 topically to stadium of 24 hours did not show any distinct effect to its ecdysteroid titre until the sixth day. On the seventh day, ecdysteroid titre dropped significantly until it began making a cocoon. Larvae treated with low dose at a stadium of 48, 72, and 96 hours showed a reduction in their ecdysteroid titre starting from the fifth day to the seventh day and would increase again on the eight day, when they began making cocoon.

The maximum titre peak of haemolymph ecdysteroid in control larvae obtained in this experiment on the seventh day did not differ with the result of the study conducted by Trivedy et al., (1995) and Gu \& Chow (1996). Ecdysteroid titre increased from $3 \mathrm{ng} / \mathrm{ml}$ on the first day to $70 \mathrm{ng} / \mathrm{ml}$ on the second day, then was sustained on the level between 70 to 136 $\mathrm{ng} / \mathrm{ml}$ during the second and fifth day, while the highest titre peak occurred on the seventh day (Gu \& Chow, 1996). But, it was different from the result of the research by Thyagaraja et al., (1991) where the highest titre peak of the haemolymph ecdysteroid of control was measured on the eleventh day of the fifth instar of B. mori. While in larvae treated with thyroxine, the highest titre peak of the ecdysteroid occurred on the tenth day. It is possible that the difference was probably due to a difference in the strain of silkworm used and environmental factors.

\section{Acknowledgements}

This work was partly supported by a competitive grant from the Directorate General of Higher Education Republic of Indonesia given to Intan Ahmad.

\section{References}

Akai, H., Kimura, K., Kiguchi, M. and Shibukawa, K. 1985. An increase of silk production by repeated treatment with a juvenile hormone analogue. J. of Sericultural Science of Japan 54: 297- 299

Beydon, P. 1985. Biosynthese Et Inactivation De L'Hormone De Mue Au Courrs Du Developpentment Postembryonnaire Chez Pieris brassicae (Insecte Lepidoptere). These De Doctorat D'etat.

Gu, S.H. and Chow, Y.S. 1996. Regulation of Juvenile Hormone Biosynthesis by Ecdysteoid Level During The Early Stages of The Last Two Larva Instar of Bombyx mori. J. Insect. Physiol 42 (7): 625-632.

Miranda, JE, de Bortoli, S.A and Takahashi, R. 2002 Development and Silk Production by Silkworm Larvae after Tropical Application of Methoprene. Scientia Agricola 59 (3): 585-588.

Sakurai, S., Kaya, M. and Sakate, S.I. 1998. Haemolymph Ecdysteroid Titre and Ecdysteroid-Dependen Developmental Events in the Last-Larval Stadium of The Silkworm, Bombyx mori: Role of of Low Ecdysteroid Titre in Larval-Pupal Metamorphosis and a Reappraisal of The Head Critical Period. J. Insect Physiol 44: 867-881. 
Thyagaraja, B.S., Kelly, T.J., Masler, E.P. and Borkovec, A.B. 1991. Thyroid Induced Haemolymph Protein and Ecdysteroid Increases in the Silkworm, Bombyx mori L.: Effect of Larva Growth and Silk Production. J. Insect. Physiol 37: 153-159.

Trivedy, K., Porcheron, P., Latfont, R., Magadum, S.B. and Datta, R.K. 1995. Alterations of Ecdysteroid Titre and Spinning by Juvenile Hormone Analogue R394 in Silkworm, Bombyx mori. XVIth International Sericulture Congress. Bandung.

Tuberty, S.R. and McKenney, C.L. 2005. Ecdysteroid Responses of Estuarine Crustaceans Exposed Through Complete Larval Development to Juvenile Hormone Agonist Insecticides. Integr. Comp. Biol. 45: 106-117.

Watson, R.D., Agui, N., Haire, M.E. and Bollenbacher, W.E. 1987. Juvenile Hormone Coordinates The Relation of The Haemolymph Ecdysteroid Titre During Pupal Commitment in Manduca sexta. J. Insect Biochem 17 (7): 955-959. 